\title{
The Subterranean Fauna of Križna Jama, Slovenia
}

\author{
Slavko Polak ${ }^{1, *}$ and Tanja Pipan ${ }^{2}$ (D) \\ 1 Notranjska Museum Postojna, Zavod Znanje Postojna, Kolodvorska Cesta 3, SI-6230 Postojna, Slovenia \\ 2 Research Centre of the Slovenian Academy of Science and Arts, Karst Research Institute, Novi trg 2, \\ SI-1000 Ljubljana, Slovenia; tanja.pipan@zrc-sazu.si \\ * Correspondence: slavko.polak@notranjski-muzej.si
}

check for updates

Citation: Polak, S.; Pipan, T. The Subterranean Fauna of Križna Jama, Slovenia. Diversity 2021, 13, 210. https://doi.org/10.3390/d13050210

Academic Editor: Michael Wink

Received: 21 April 2021

Accepted: 13 May 2021

Published: 15 May 2021

Publisher's Note: MDPI stays neutral with regard to jurisdictional claims in published maps and institutional affiliations.

Copyright: (c) 2021 by the authors. Licensee MDPI, Basel, Switzerland. This article is an open access article distributed under the terms and conditions of the Creative Commons Attribution (CC BY) license (https:/ / creativecommons.org/licenses/by/ $4.0 /)$.

\begin{abstract}
The karstic cave Križna jama in the South Western part of Slovenia is one of the largest, well known and most beautiful Slovene water caves. The cave consists of more than $8 \mathrm{~km}$ of corridors with impressive halls, colossal dripstone formations, a subterranean river and numerous lakes. Considering the subterranean fauna, Križna jama has been identified amongst the richest caves in the world. So far, 60 troglobionts, the obligate subterranean species among them 32 aquatic and 28 terrestrial taxa have been recorded and documented. Križna jama has scientific importance, as well as ten subterranean taxa, which have been described based on specimens from this cave. Despite Križna jama is relatively well-studied, new recent unexpected findings are promising. Thus, further discoveries of specialized subterranean species in the cave are expected.
\end{abstract}

Keywords: caves; Križna jama; biospeleology; subterranean biodiversity; hotspots; troglobiont; checklist

\section{Introduction}

Križna jama (registered in Slovene Cave Cadaster, Cad. No. 65) is developed under the Križna gora $(857 \mathrm{~m})$ hill near the village Lož in the South Western part of Slovenia. It is one of the largest, well known and most beautiful Slovene water caves. Due to its natural beauty, it has been promoted in the Slovene edition of National Geographic magazine [1]. In the first global subterranean biodiversity comparative study [2], Križna jama was listed among the richest caves of the Dinaric range. The cave consists of $8273 \mathrm{~m}$ of corridors with impressive halls, colossal dripstone formations, a subterranean river and many lakes (Figure 1). The main passage, called Jezerski or Glavni rov, located approximately in the middle of the cave, at a spot named "Kalvarija", bifurcates into two separate corridors: Pisani rov and Blatni rov or Blata (Figure 2). Cavers recently discovered some new unknown and still unmeasured passages (Troha A. per. comm.). The cave is mainly horizontal with a difference of only $32 \mathrm{~m}$ between the highest and the lowest point of the cave. The lowest drypoint is at the water level of the lakes in Kittl shafts or Kittlova brezna, where the subterranean river sinks into the passage that cannot be accessed.

The unique features of Križna jama are its breathtaking clean and emerald green subterranean lakes (Figure 1). In two passages, Jezerski and Pisani rov, there are 22 lakes. Summing these to the lakes in Blatni rov, there are 45 lakes in Križna jama altogether. During the rainy seasons, the running water on its way through the karstic massif dissolves limestones and saturates with calcium carbonate. On its course through the cave, streams deposit carbonates on the riverbeds. Especially on its stream rapids, the permanently deposited sinter creates rimstone barriers that dam and accumulate numerous lakes. An average rate of sinter deposition in Križna jama is estimated to be approx. $0.256 \mathrm{~mm}$ per year [3]. From a geological and hydrological point of view, Križna jama is located in a syncline between the Bloke plateau and the Idrija fault zone, where the karstic Ljubljanica river flows through a series of karst poljes. It lies within the aquifer of the triangle formed by the Bloke plateau $(720 \mathrm{~m})$, the Cerknica polje $(550 \mathrm{~m})$ and the Loško polje $(575 \mathrm{~m})$. 
The oldest rocks of the syncline are the Upper Triassic dolomites, while the youngest are the Upper Jurassic limestones. Between them, there are a series of limestone strata, with lenses or nests of dolomites. The syncline shows a relatively weak faulting but local faults, together with tectonised bedding planes, can guide the formation of some Križna jama passages $[4,5]$.

During periods of low water levels, Križna jama is mainly characterised by the flow of percolated water from the nearby hilly karst area. When water levels are high, Križna jama drains a small extent of allogenic water from the Bloke plateau, mainly from the Blošcica and the Farovščica streams too [5]. Underground water courses and connections have been elucidated by a series of tracer tests [6,7]. The water flowing through Križna jama sinks near the cave entrance in the deep Kittl shaft or abyss which ends with a syphon and reapers downstream in the Štebrščica spring at the edge of the Cerknica polje [6]. Speleo-divers tried to follow the stream in the Kittl shaft in an attempt to find further subterranean connections. Passing the flooded syphons at the depth of $70 \mathrm{~m}$ however, appears to be technically too difficult. Instead, cavers in the attempt to find easier access to the subterranean cave passages, tried to find some hidden entrance on the surface. In a long-term effort after $200 \mathrm{~h}$ of digging, in 1991 cavers finally enlarged a small hole (known as Dihalnik v Grdem dolu). Until that time, only the edible dormice (Glis glis) have regularly used this small entrance. This new small entrance led to the discovery of additional $1415 \mathrm{~m}$ long virgin cave, popularly called "Križna jama 2". Due to the fragile dripstone formations, this cave is extremely sensitive to visit. After proper investigation and measuring, this cave has been closed and strictly protected, with less than 30 cavers ever visited it. Although it is undoubtedly part of the same cave system, Križna jama 2 (registered in Slovene Cave Cadaster, Cad. No. 6286, as Dihalnik v Grdem dolu) is considered as a separate cave object from Križna jama.

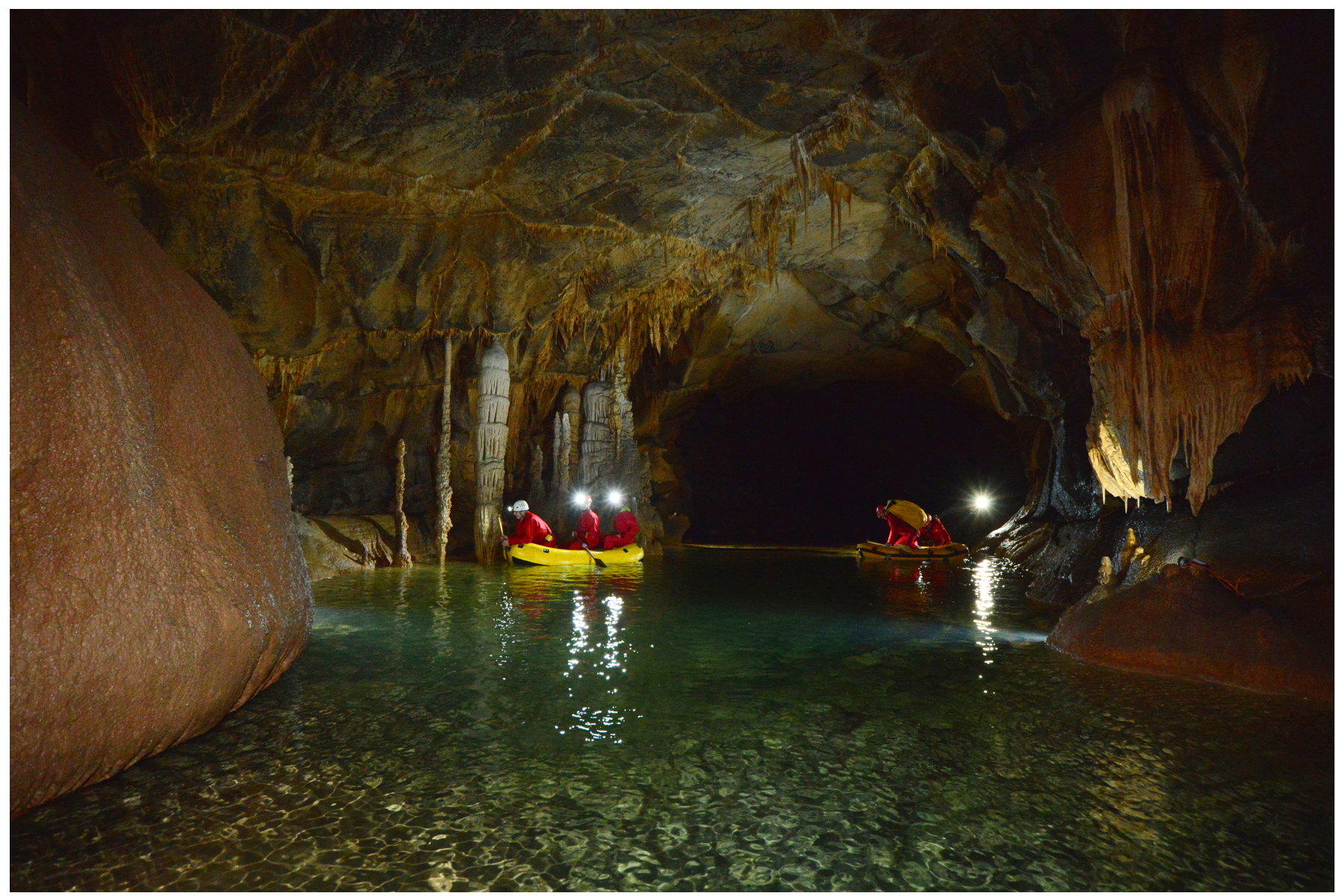

Figure 1. The unique features of Križna jama are its breathtaking clean and emerald green subterranean lakes. 


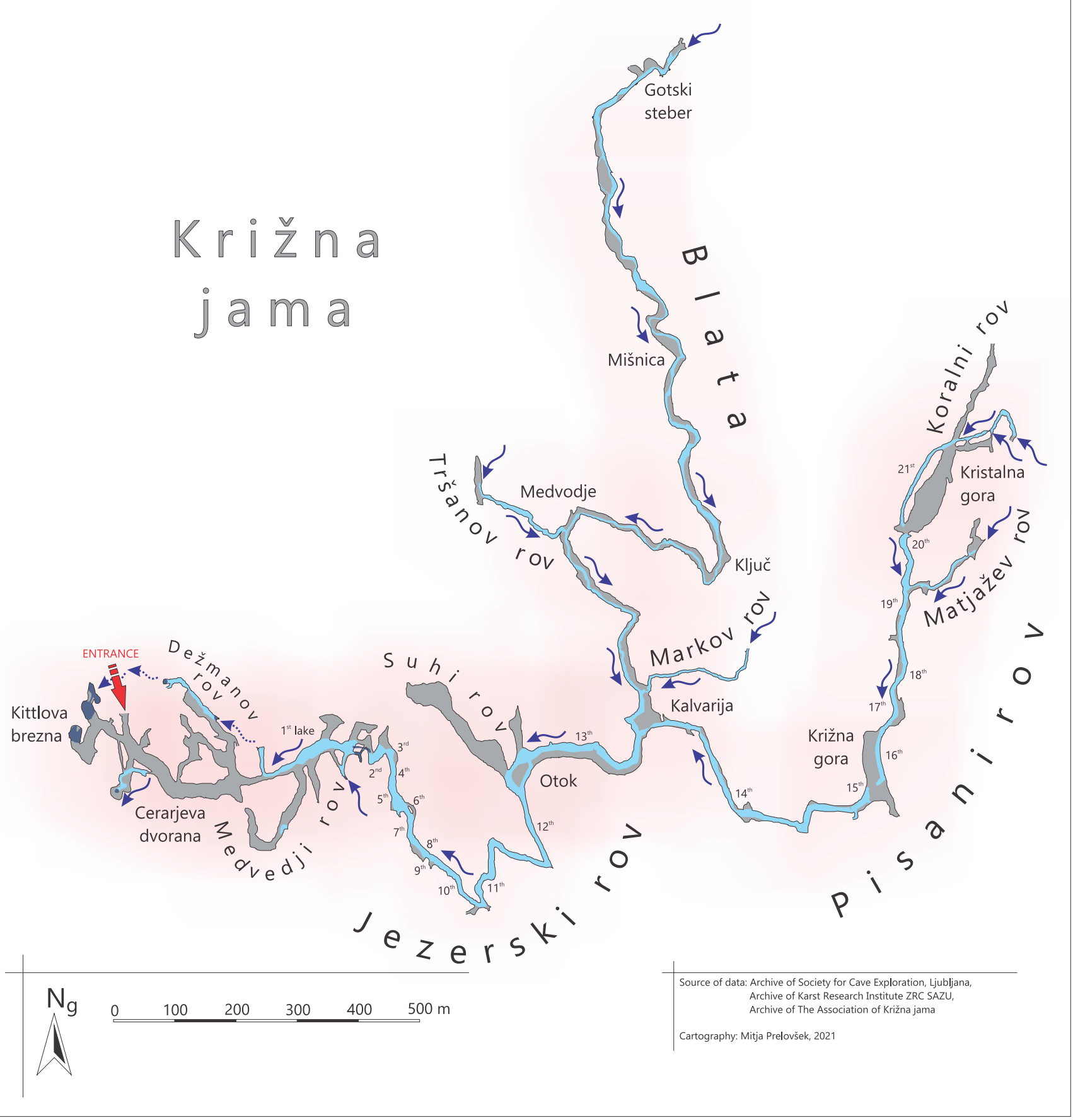

Figure 2. Plan of Križna jama. Archive of Karst Research Institute ZRC SAZU, cartography Mitja Prelovšek.

Križna jama crystal clean lakes and dripstone formations attracted numerous explorers, cavers and visitors early in the 20th century. Uncontrolled visits in the early time resulted in some damage of dripstone formations and local pollution of the cave. The local cavers soon closed the entrance and within a couple of volunteer actions successfully cleaned up the cave. Križna jama nowadays accepts about 10,000 guided visitors per year, but only a small part of the visitors are lucky enough to enjoy the beautiful lakes in the inner parts of the cave by boat. Due to the fragility of the sinter dripstones and the sensitivity of the cave, the number of guided visits is limited and strictly controlled. 


\section{Materials and Methods}

To complete an updated list of troglobiotic fauna in Križna jama, we consulted the available literature. Species recognized as troglophiles and trogloxenes are discussed in the text but not listed in Table 1. In searching for subterranean fauna reports in dispersed publications within the last, almost 200 years, we encountered difficulties concerning the different names used for Križna jama. In our review we recorded many different names, all referring to Križna jama: Mrzla jama am Fuss des Kreuzgeberges [8], Berühmte Grotte von Podlaz [9], Mrzla Jama [10], Krizna jama, ou Kreuzöhle sur le versant D. du Kreuzberg [11], Mrzla jama, á Blazka Poliza, distr. De Logatesc and Krizna jama/Kreuzhöhle/sur le Kreuzberg, prés de Lass [12] and Kreuzberghöhle (1700 m N Laas and N Hang des Kreuzberges) [13]. Križna jama [14] cave should not be mistaken with another cave with a similar name-Mrzla jama pri Ložu (registered in Slovene Cave Cadaster, Cad. No. 79), located $1.7 \mathrm{~km}$ heading south. A third "Mrzla jama" cave (1.5 km heading north) is a small cave with a water stream called Mrzla jama pri Bločicah (registered in Slovene Cave Cadaster, Cad. No. 1176). The fauna of all these three caves is however similar or probably equal.

Table 1. An updated list of stygobiotic and troglobiotic species encountered in the Križna jama. Tb.--terrestrial (troglobiont), Stb.-aquatic (stygobiont), Stb. pop.-stygobiotic population, Tl.-type locality in Križna jama, new—new, unpublished data.

\begin{tabular}{|c|c|c|c|c|}
\hline Taxonomic Group & Familia & Genus/Species/Subspecies & Status & References \\
\hline Ciliata & Lagenophryidae & Lagenophrys monolistrae Stammer, 1935 & Stb. & {$[14,15]$} \\
\hline Turbellaria & Dendrocoelidae & Dendrocoelum cf. spelaeum (Kenk, 1924) & Stb. & [14] \\
\hline Turbellaria & Scutariellidae & Stygodyticola hadzii Matjašič, 1958 & Stb. & {$[14,16]$} \\
\hline Gastropoda & Hydrobiidae & Belgrandiella superior Kuščr, 1932 & Stb. & {$[14,17,18]$} \\
\hline Gastropoda & Hydrobiidae & Belgrandiella crucis (Kuščer, 1928) & Stb., Tl. & {$[13,14,19]$} \\
\hline Gastropoda & Hydrobiidae & Belgrandiella schleschi (Kuščer, 1932) & Stb., Tl. & {$[13,14,19]$} \\
\hline Gastropoda & Hydrobiidae & Hauffenia michleri Kuščer, 1932 & Stb. & {$[13,14,19]$} \\
\hline Gastropoda & Moitessieriidae & Phaladilhiopsis sp. & Stb. & [14] \\
\hline Gastropoda & Ellobiidae & Zospeum exiguum Kuščer, 1932 & Stb., Tl. & {$[14,18-20]$} \\
\hline Gastropoda & Ellobiidae & Zospeum kusceri A. J. Wagner, 1912 & Tb. & {$[14,18,20]$} \\
\hline Gastropoda & Ellobiidae & Zospeum isselianum Pollonera, 1887 & $\mathrm{~Tb}$. & {$[14,18,20]$} \\
\hline Oligochaeta & Haplotaxidae & Delaya bureschi (Michaelsen, 1925) & Stb. & [14] \\
\hline Oligochaeta & Lumbriculidae & Trichodrilus strandi Hrabe, 1936 & Stb. & [14] \\
\hline Oligochaeta & Lumbriculidae & Trichodrilus ptujensis Hrabe, 1963 & Stb. & [14] \\
\hline Oligochaeta & Lumbriculidae & Trichodrillus pragensis Vejdovsky, 1876 & Stb. & [14] \\
\hline Oligochaeta & Naididae & $\begin{array}{l}\text { Rhyacodrilus omodeoi Martinez-Ansemil, Sambugar } \\
\text { \& Giani, } 1997\end{array}$ & Stb., Tl. & [14] \\
\hline Oligochaeta & Naididae & Rhyacodrilus sketi Karaman, 1974 & Stb. & [14] \\
\hline Oligochaeta & Naididae & Tubifex pescei (Dumnicka, 1980) & Stb. & {$[14]$} \\
\hline Ostracoda & Entocytheridae & Sphaeromicola sp. & Stb. & [14] \\
\hline Copepoda & Canthocamptidae & Elaphoidella jeanneli (Chappuis, 1928) & Stb. & [14] \\
\hline Copepoda & Canthocamptidae & Elaphoidella stammeri Chappuis, 1936 & Stb. & [14] \\
\hline Copepoda & Canthocamptidae & Lessinocamptus n.sp. Stoch unpubl. & Stb., Tl. & {$[14,21]$} \\
\hline Copepoda & Canthocamptidae & $\begin{array}{l}\text { Bryocamptus (Rheocamptus) balcanicus s.l. } \\
\text { (Kiefer, 1933) }\end{array}$ & Stb. & [14] \\
\hline Copepoda & Cyclopidae & Megacyclops viridis s.l. (Jurine, 1820) & Stb. & [14] \\
\hline Copepoda & Cyclopidae & Acanthocyclops kieferi (Chappuis, 1925) & Stb. & [14] \\
\hline Copepoda & Cyclopidae & Acanthocyclops troglophilus (Kiefer, 1932) & Stb. & [14] \\
\hline Copepoda & Cyclopidae & Diacyclops languidoides goticus Kiefer, 1931 & Stb. & [14] \\
\hline Copepoda & Cyclopidae & Diacyclops charon (Kiefer, 1931) & Stb. & [14] \\
\hline Copepoda & Cyclopidae & Speocyclops infernus (Kiefer, 1930) & Stb. & [14] \\
\hline Amphipoda & Niphargidae & Niphargus orcinus Joseph, 1869 & Stb., Tl. & {$[13,14,22]$} \\
\hline Amphipoda & Niphargidae & Niphargus wolfi Schellenberg, 1933 & Stb. & [14] \\
\hline Amphipoda & Niphargidae & Niphargus stygius (Schiödte, 1847) & Stb. & [14] \\
\hline Amphipoda & Crangonyctidae & Synurella ambulans (F. Müller, 1846) & Stb. pop. & [14] \\
\hline
\end{tabular}


Table 1. Cont.

\begin{tabular}{|c|c|c|c|c|}
\hline Taxonomic Group & Familia & Genus/Species/Subspecies & Status & References \\
\hline Isopoda & Trichoniscidae & Titanethes albus (C. Koch, 1841) & $\mathrm{Tb}$. & [14] \\
\hline Isopoda & Trichoniscidae & Androniscus stygius tschameri Strouhal, 1935 & $\mathrm{~Tb}$ & {$[14,23]$} \\
\hline Isopoda & Sphaeromatidae & Monolistra racovitzai Strouhal, 1928 & Stb., Tl. & {$[13,14,24]$} \\
\hline Araneae & Dysderidae & Stalita taenaria Schiödte, 1847 & $\mathrm{~Tb}$ & {$[10,13,14,25-28]$} \\
\hline Araneae & Dysderidae & Parastalita stygia (Joseph, 1882) & $\mathrm{Tb}$. & {$[10,13,14,26,28]$} \\
\hline Araneae & Dysderidae & Mesostalita nocturna (Roewer, 1931) & $\mathrm{Tb}$. & new \\
\hline Araneae & Linyphiidae & Troglohyphantes excavatus Fage, 1919 & $\mathrm{~Tb}$. & {$[10,13,14,29,30]$} \\
\hline Pseudoscorpiones & Neobissidae & Neobisium spelaeum (Schiödte, 1847) & $\mathrm{Tb}$. & {$[14,31]$} \\
\hline Pseudoscorpiones & Chthoniidae & Chthonius (Globochthonius) speleophylus Hadži, 1930 & $\mathrm{~Tb}$. & {$[14,32]$} \\
\hline Opiliones & Nemastomatidae & Hadzinia ferrani Novak \& Kozel, 2014 & $\mathrm{~Tb}$. & [33] \\
\hline Diplopoda & Attemsiidae & Attemsia falcifera Verhoeff, 1899 & $\mathrm{~Tb}$. & {$[13,14,34]$} \\
\hline Diplopoda & Anthogonidae & Haasia largescutata paligera (Strasser, 1940) & $\mathrm{Tb}$. & [35] \\
\hline Diplopoda & Polydemidae & Brachydesmus inferus concavus Attems, 1898 & $\mathrm{~Tb}$. & {$[35,36]$} \\
\hline Diplura & Campodeidae & Plusiocampa (Stygiocampa) nivea (Joseph, 1882) & $\mathrm{Tb}$. & {$[13,14,25]$} \\
\hline Collembola & Arrhopalitidae & Arrhopalites/Pygmarrhopalites sp. & $\mathrm{Tb}$. & [10] \\
\hline Collembola & Paronellidae & Troglopedetes pallidus Absolon, 1907 & $\mathrm{~Tb}$. & new \\
\hline Collembola & Oncopoduridae & Oncopodura cavernarum Stach 1934 & $\mathrm{~Tb}$. & new \\
\hline Collembola & Onychiuridae & Absolonia gigantea (Absolon, 1901) & $\mathrm{Tb}$. & new \\
\hline Collembola & Onychiuridae & Onychiurus/Onychiurides sp. & $\mathrm{Tb}$. & new \\
\hline Collembola & Tomoceridae & Tritomurus scutellatus Frauenfeld, 1854 & $\mathrm{~Tb}$ & {$[10,13,14]$} \\
\hline Coleoptera & Carabidae & Typhlotrechus bilimekii frigens Jeannel 1928 & Tb., Tl. & {$[13,14,37,38]$} \\
\hline Coleoptera & Carabidae & Anophthalmus heteromorphus (G. Müller 1923) & Tb., Tl. & {$[13,14,37-40]$} \\
\hline Coleoptera & Staphylinidae & Machaerites ravasinii G. Müller, 1922 & $\mathrm{~Tb}$. & {$[14,41-44]$} \\
\hline Coleoptera & Leiodidae & $\begin{array}{l}\text { Bathyscimorphus (Drovenikia) trifurcatus } \\
\text { Jeannel, } 1924\end{array}$ & Tb., Tl. & {$[12-14,45,46]$} \\
\hline Coleoptera & Leiodidae & Bathysciotes khevenhuelleri (Miller, 1852) & $\mathrm{Tb}$. & [12-14] \\
\hline Coleoptera & Leiodidae & Aphaobius milleri (Schmidt, 1855) & $\mathrm{Tb}$. & {$[12-14,47]$} \\
\hline Coleoptera & Leiodidae & Leptodirus hochenwartii Schmidt, 1832 & $\mathrm{~Tb}$. & {$[8,11-14]$} \\
\hline
\end{tabular}

In the stygobiotic and troglobiotic faunal checklist (Table 1), we report only valid names of taxa. Those were checked using online world taxa databases as WoRMS for aquatic taxa and MilliBase, Pseudoscorpions of the World, MolluscaBase, etc. For some taxa, we updated recently synonymized names. Species listed in the former checklist that are not accepted as valid taxa were excluded from the list. In the older literature, some dubious records are persistently appearing. For the precautionary reason, we excluded such taxa from the list if the specimens were not collected or reported recently. In some cases, taxonomic experts explicitly stated that specimens found in Križna jama belong to a new, yet undescribed species.

As the last published checklist of Križna jama troglobionts [14] was mostly focused on aquatic fauna and there was a lack of terrestrial fauna studies, in the autumn of 2020 and early spring of 2021, we sampled the terrestrial fauna. In a few excursions, we investigated the cave up to the point called Križna gora (Figure 2). We searched for fauna mostly by eye on speleothems, cave walls, among rocks and especially near the bat guano deposits. The use of rubber boats, provided by the managers of Križna jama, was essential to investigate deeper parts of the cave. To collect additional terrestrial fauna we deployed a smaller number of plastic pit-fall traps along the transect in the surveyed cave corridor. The traps were baited with cheese and rotten meat. As the traps were without a fixative, we examined them after five days. We took macrophotographs of most of the captured animal species "in situ" in the cave. Specimens needed for future research were stored in alcohol and are deposited in the Zoological Collection of the Notranjska Museum Postojna. Collembolan fauna was preliminarily determined by Marko Lukić (Zagreb) but a detailed study of the collected specimens is still pending. Especially at the cave entrance, we sifted the soil and gravel with entomological sieves but using this method we did not find any significant troglobiotic fauna. During our recent field trips, we also sampled aquatic fauna. Larger crustaceans were sampled with aquatic nets in the water of the cave river, pools and lakes. 
Some of the sampled aquatic fauna was later photographed in the laboratory. A large sample of gravel and silt was collected from the bottom of the lakes, sieved and examined in the laboratory to study smaller invertebrate species, especially molluscs and annelids. Microscopic slides with informative details of the species were made for the identification of some invertebrate species. In some cases, taxa are identified to genus level since no detailed and final study on the collected specimens is made.

\section{Results}

\subsection{A Historical Overview}

Local people have been visiting Križna jama for millennia. Evidence of that are fragments of pottery dating from the Bronze Age found within the cave. The oldest signature found on a cave wall is dated back to 1557. The first explorations of the cave are documented by the evidence that Jožef (Josip) Cerar (in German Johann Zörrer) visited Križna jama in November 1824 and in July 1825 with a group of local people from Lož and Cerknica. His report, the cave description and its first map, unfortunately, did not appear until 1838 [48]. He was the first to report that some cave passages contain cave bear (Ursus speleus) bones. In his report, he used the German name of the cave "Heiligen-kreutz", despite the locals knew the cave as "Mrzla jama" (cold cave). The first known printed account of this cave comes from an Englishman John James Tobin diary who accompanied Sir Humphry Davy douring his cave visit, in 1832. At that time, only the first $500 \mathrm{~m}$ or so of the cave were accessible and known. Tobin's report of proteus (Proteus anguinus) seen in the cave is very interesting [49]. Soon after that, Aleksander Škofic in 1847 and Adolf Schmidl in 1854 wrote detailed descriptions of the cave. Their reports about plenty of cave bear bones and teeth made Križna cave famous. These reports encouraged the Austrian geologist Ferdinand von Hochstetter to start digging bones in Križna jama in 1878 and 1879. Hochstetter and his workers collected out an impressive number of 4600 cave bear bones from more than 100 individuals [50]. Two complete cave bear skeleton reconstructions, displayed in the Museum of Natural History in Vienna, originated from this time [51]. The first to report about the presence of the cave slender-neck beetle Leptodirus hochenwartii in Križna jama was Heinrich Müller in 1857 [8]. The German naturalist Gustav Joseph visited several Slovenian caves in the period from 1853 to 1881. Despite the fact that his collection is not preserved, he published basic data about the Križna jama fauna in one of his publications [10]. Additional faunal reports from Križna jama can be found in Hamann's catalogue [25]. In the 19th century, mostly cave beetle collectors visited Križna jama. There were Eduard Knirsch, Joseph Müller, Anton Haucke, Josip Sever, Alfonz Gspan, Ivan Dolar and Egon Pretner. Roman Kenk and Albin Seliškar visited Križna jama in 1928 and first collected aquatic fauna as well. Ljudevit Kuščer studied and published descriptions of some Križna jama new subterranean snails $[17,19]$. The first list of Križna jama fauna reported and described taxa by various European leading taxa specialists $[12,24,52]$ was published in Wolf's catalogue [13]. After World War II, Egon Pretner made many visits to Križna jama, mostly leading foreign and other Slovene biologists who sampled the fauna. Jože Bole investigated the gastropods of Križna jama and its surrounding springs [18,53]. From the $70^{\prime}$ s onwards, Boris Sket and his colleagues visited Križna jama on several excursions and gathered samples, mainly focusing on aquatic fauna [14]. Nevertheless, no detailed ecological investigations have been done in the cave. Based on collected samples, significant progress has been made about the presence of some less investigated animal groups, such as Oligochaeta [54,55]. Sket published a second paper in Slovene about the Križna jama fauna in 1986 [56], and a scientific overview with Fabio Stoch in 2014 [14]. Recently, the authors carried out an additional survey, mainly focused on terrestrial fauna. In this paper, new and so far unpublished data on the presence of some terrestrial troglobiotic fauna is given. 


\subsection{The Subterranean fauna of Križna Jama}

The entrance hall of Križna jama is voluminous and due to the artificially enlarged entrance, daylight penetrates deep inside the cave. Within the first part of the cave next to the entrance, numerous troglophilic and trogloxene animals can be regularly seen. Especially in winter geometrid moths Triphosa dubitata and noctuids Scoliopteryx libatryx, as well as cave crickets (Troglophilus spp.), are common as parietal fauna on the walls. Different species of harvestmen (Opiliones), spiders (Araneae), caddisflies (Trichoptera) and various flies and mosquito (Diptera) considered as troglophiles and trogloxenes are common here. In the bottom of the entrance hall rich with humus, some other soil fauna, not considered as troglobiotic, is present. Stone martens (Martes foina) and edible dormice (Glis glis) regularly penetrate deeper into the cave corridors. On the contrary, the tawny owl (Stryx aluco) is usually found dormant only at the cave entrance.

So far, seven species of bats have been recorded in Križna jama [57,58]. The most common is the lesser horseshoe bat (Rhinolophus hipposideros). It overwinters in both Križna jama and in Križna jama 2 in significant numbers. Regularly about 900 individuals overwinter here and this represents the second-highest concentration of bats compared to other Slovene caves [58]. Other species like the great mouse-eared bat (Myotis myotis), Daubenton's bat (Myotis daubentonii), the serotine (Eptesicus serotinus) and the barbastelle bats (Barbastella barbastellus) are occasionally found in smaller numbers. Schreibers' bat (Miniopterus schreibersii) have so far been spotted in Križna jama only once [58]. There are no bat breeding colonies in Križna jama. Bat parasites such as the bat thick (Ixodes vespertilionis) can be regularly found on walls next to the hibernating bats. Numerous troglophilic and troglobiotic collembolans, mites, diplopods and beetles are attracted by owl pellets and bat guano as well as by marten scats and dormice droppings all over the cave.

Among the troglobionts cave beetles are relatively numerous. The most famous of all, the slenderneck beetle Leptodirus hochenwartii, is rare and mostly found in the deeper cave spaces far from the entrance. In the entrance hall, as well all along the immense cave tunnels of Križna jama, the small bathyscioid leptodirine beetle Bathyscimorphus trifurcatus (Figure $3 b$ ) is the commonest troglobiotic beetle $[11,45,46]$. The leptodirine beetle Bathysciotes khevenhuelleri is regularly trapped in pitfall traps in the entrance hall between the stones and the soil in the habitat that resembles the MSS, while the leptodirine Aphaobius milleri have been collected only sporadically [47]. Bathysciotes khevenhuelleri is relatively common in Snežnik-Javorniki wider area in mesovoid shallow substratum (or "Milieu souterrain superficiel"-MSS) [59], while Aphaobius milleri prefers to some extent colder cave microclimates in the area which can be found right after the Križna jama entrance. Two species of troglobiotic ground beetles are known from Križna jama and for both taxa Križna jama is their type locality. The subspecies of the trechine Typhlotrechus bilimeki frigens (Figure 3a) is relatively common $[37,38]$ in many places, while the endemic Anophthalmus heteromorphus is extremely rare and thus much sought by collectors [38-40]. The troglobiotic pselaphine beetle Machaerites ravsinii is occasionally found among the rocks in the entrance hall of Križna jama [41-44]. Some other subterranean beetle species occasionally reported for Križna jama are doubtful and need further recent confirmation.

The Collembolan fauna of Križna jama has not been studied in details until recently. Joseph [10] described two species of Sminthurus from Križna jama, but they are not considered valid in later works. In Wolf's catalogue [13] there are records of five species of collembolans, which were questioned as doubtful in the last Križna jama list of troglobionts [14]. In recent samplings, the collembolan species Troglopedetes pallidus (Figure 3b), Oncopodura cavernarum, Absolonia gigantea and some undefined species of Onychuiridae and Arrhopalitidae are documented. Small, eyeless and strongly troglomorphic collembolan specimens of taxonomically not yet determined species of the complex Arrhopalites/Pygmarrhopalites (Figure 3e) can be found on bat guano regularly. Troglobiotic collembolans are all common on the bat guano and similar organic debris, especially stone marten scats in deeper parts of the cave. Tritomurus scutellatus is common only near the entrance, but still within the cave's 
dark zone. The dipluran species Plusiocampa (Stygiocampa) nivea is rare but widespread in Križna jama.
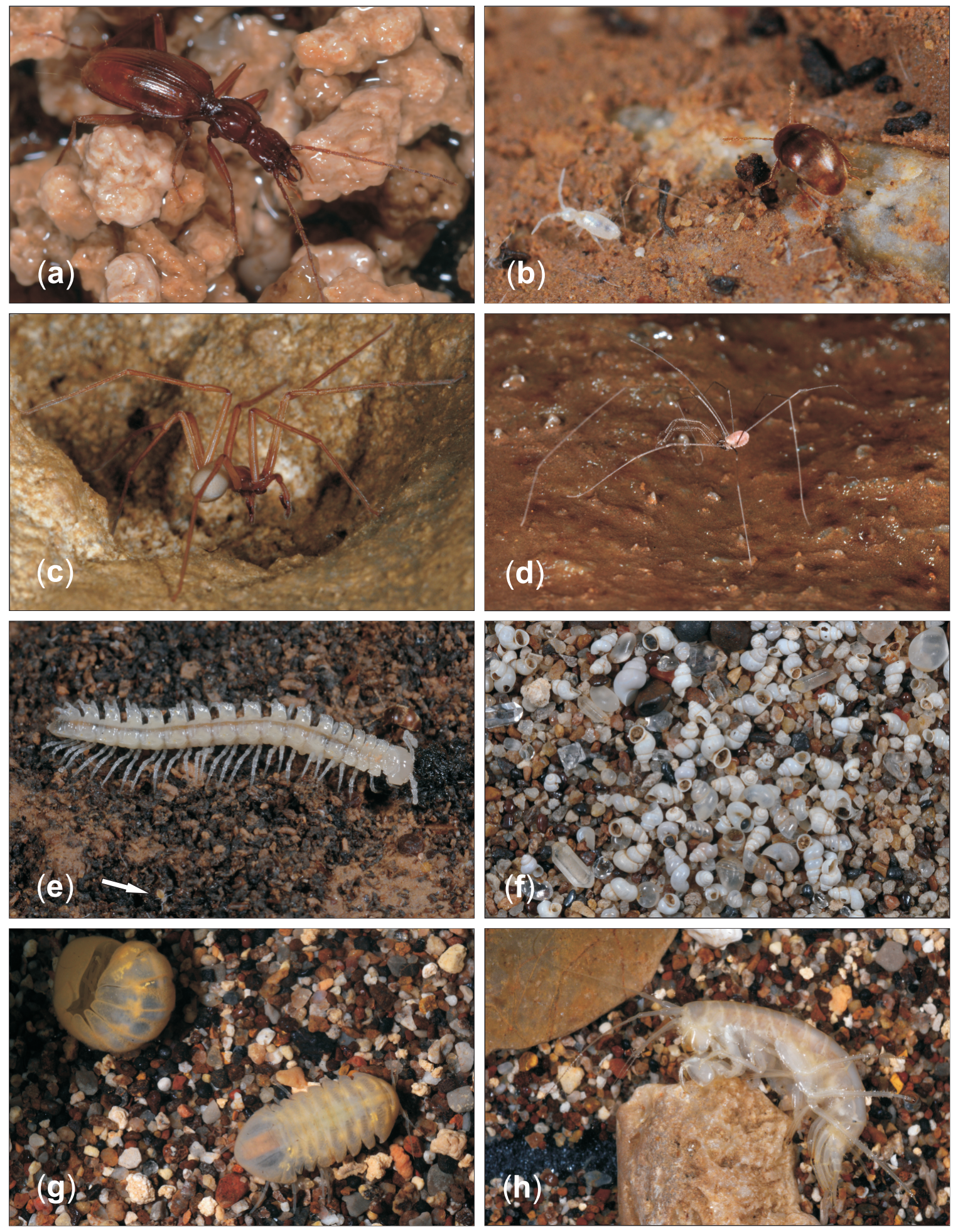

Figure 3. Troglobiotic and stygobiotic fauna from Križna jama: (a) Ground beetle (Typhlotrechus bilimekii frigens). (b) Leptodirine beetle (Bathyscimorphus (Drovenikia) trifurcatus), on the right and Collembolan (Troglopedetes pallidus), on the left. (c) Cave spider (Parastalita stygia). (d) Cave Harvestman (Hadzinia ferrani). (e) Cave Millipede (Brachydesmus inferus concavus) and Collembolan (Pygmarrhopalites sp.), indicated with white arrow. (f) Various species of aquatic snails from family Hydrobiidae and quartz crystals. (g) Sphaeromatid isopod (Monolistra racovitzai). (h) Cave amphipod (Niphargus orcinus). 
The troglobiotic arachnid fauna of Križna jama is rich as well. So far, only one of the lyniphiid Troglohyphantes species is reported from Križna jama [10,14,27,29,30]. The troglobiotic dysderid spider species Stalita taenaria and Parastalita stygia (Figure 3c) live in Križna jama sympatrically [26-28]. The coexistence of these two related species in the same cave is rare [60]. Surprisingly enough, a third distinctly smaller dysderid species Mesostalita nocturna was found deep inside Križna jama during one of the last excursions (Delić T. per. comm.). In one of the recent ecological studies [60], it was demonstrated that the shift in the trophic niche amongst related species minimizes the interspecific competition and enables related dysderid spider species coexistence. The fact that the Križna jama is a tourist cave and is regularly visited, the recent discovery of fully troglomorphic harvestmen was an unexpected surprise. A detailed study of the only known single male and female specimens showed that they belong to a recently described species Hadzinia ferrani (Figure 3d) from the cave Ferranova buža, situated $40 \mathrm{~km}$ northwest from Križna jama [33,61]. Amongst the pseudoscoripons in Križna jama two troglobiotic species are known [31,32]. The relatively giant Neobysium speleum is rarely encountered on wet walls and stalactites of the deeper parts of the cave. The second smaller species Chthonius (Globochthonius) spelaeophilus is reported recently from the cave too [32].

Among the Myriapod, a only troglobiotic millipedes have been recorded in Križna jama so far, although the cave centipede Lithobius stygius is expected to be found also as it was recently confirmed in nearby Mrzla jama pri Ložu [62]. The most abundant among the millipedes are the polydesmid Brachydesmus inferus concavus (Figure 3e) [35,36,63], which was reported as B. subterraneus or B. sp. in former works $[13,14]$. On any organic material, even in the deeper parts of the cave, all development stages (larvae and mating adults) of this millipede are commonly seen. Two other millipede species, Attemsia falcifera $[13,14,34]$, reported as A. pretneri in older works and Hassia largescutata paligera, reported as Acherosoma cornuatum paligerum, endemic species of the region, are living in Križna jama too [35,63-65].

Two species of terrestrial isopod crustaceans are regularly found in Križna jama. The giant cave woodlouse Titanethes albus lives on wet spots in deeper parts of the cave, while the smaller species Androniscus stygius tschammeri [23] is usually found on rotting wood or organic debris near the entrance of the cave. Visitors to Križna jama can regularly encounter the aquatic sphaeromatid isopod Monolistra racovitzai (Figure 3g) [13,14,24]. In some permanent cave lakes, these crustaceans slowly crawl on rocks and flooded rimstones. In the same cave lakes, the monolistrians are regularly accompanied by the relatively rarer predatory amphipod crustacean Niphargus orcinus (Figure 3h) [14,22]. This Niphargus species can reach up to $3 \mathrm{~cm}$ in length and it is a relatively giant invertebrate. Studying crustaceans specimens of the genus Monolistra and Niphargus under the microscope, the presence of ostracodan Sphaeromicola stammeri and turbellarian Stygodyticola hadzii as epizoans or exterior parasites have been found [14,16]. Two smaller amphipod species Niphargus wolfi and Niphargus stygius live in Križna jama too. While the former is usually found in loam and rimestone pools fed by percolated water dripping from the cave ceilings, N. stygius is found in cave lakes too [14]. In such pools, significant fauna of copepod crustaceans like Elaphoidella spp., Speocyclops infernus and Acanthocyclops kieferi have been sampled [14,21,66,67]. These pools can be occasionally flooded by the subterranean river during the floods. Larger waters, the lakes and mainstream rivers in both corridors of the Blata and Pisani rov, are oligotrophic and the fauna here is relatively scarce. Besides Monolistra and Niphargus, smaller copepod fauna such as Acanthocyclops troglophilus and Diacyclops charon have been recorded [14]. Despite most of the river corridor bottoms being covered in sinter deposits in some places, especially in the corridor Blata, the river bottom consists of very loose silt and loam mixed with sand. Here the large and colourful troglobiotic oligochaete Delaya bureschi is common. Six other troglobiotic oligochaetes have been recorded for Križna jama so far [14,55]. In the subterranean waters of Križna jama two species of troglobiotic turbellarians are reported as well.

In the lakes, river and streams of Križna jama, six aquatic, including four hydrobiid, snail species are found [17-19,53,68]. Based on specimens from Križna jama, two species 
Belgrandiella crucis and B. schleschi, were described. Belgrandiella superior and Hauffenia michleri, have been described from cave waters from a surrounding Ljubljanica river catchment area. Specimens of the aquatic snail from the genus Paladilhilopsis are still to be determined [14]. Aquatic snails live all along permanent water streams, where specimens can be found mainly on the bottom among the rocks, gravel and silt. In the lakes, where small amounts of organic debris drop from the surface (such as particles of fallen leaves), the populations of snails are more abundant. Besides hydrobiid snails, three species of primarily terrestrial troglobiotic snails live in Križna jama. The species Zospeum kusceri and Z. isselianum can be usually found on wet walls and stalactites. A third species Zospeum exiguum, described from Križna jama, is considered as at least a partly aquatic. Living specimens of Z. exiguum were collected mainly on the submerged rocks in lakes and streams so far $[19,20]$. However, the easiest way to collect empty snail shells is to collect sand on certain spots on the lake edges, where empty shells are deposited in significant numbers as a tanatocenoses (Figure 3f).

Sifting gravel and sand samples from the mainstream pools, in search of snails, recently revealed unexpected cave sedimentary deposits. In previous Križna jama fluvial sediment studies $[69,70]$ allochthone oolitic bauxite ooids and quartz pebbles amongst the autochthonous fragments of broken sinter were noted. Searching for snails, we found tiny quartz crystals of a special biterminated shape as well (Figure 3f). Most of the quartz crystals in Križna jama are notably eroded, but some brilliant specimens can be found as well. Such biterminated quartz crystals, popularly called "cerknica diamonds", are unique and in the region known from the narrow strip of land characteristic by porous sucrose dolomites on the Slivnica Mountain on the eastern side of Cerknica [71]. Accompanied by bauxite ooids, these fluvial sediments clearly show their origin and a fluvial transport from Slivnica-Bloke plateau and demonstrate the river catchment area of at least part of Križna jama running waters. Identification of water catchment area that drains into the Križna jama water system is essential for understanding zoogeographical reasons for species composition as well as for nature conservation reasons. For some rare events of periodic water pollution in the Križna jama, the source stream Farovščica in the Bloke plateau has already been identified, using water tracing methods [6].

The largest aquatic cave animal in Križna jama is to be the cave salamander or proteus (Proteus anguinus). Its presence in Križna jama was reported by Tobin in 1832 [49] later by Joseph to [10] and cited by Wolf [13]. Since then, no one has ever seen or mentioned proteus in Križna jama. Sket [72] declared this report as a "most probably erroneous" and therefore proteus has been later omitted from the fauna list of Križna jama. Proteus has a wide holo-dinaric distribution and it is present along all the Ljubljanica river drainage area. The closest confirmed localities of proteus are some wells in Loško polje, only a few kilometres away from Križna jama. Its absence in this cave is for this reason of great scientific interest. Similarly to the absence of proteus, the cave shrimp Troglocaris has never been reported in the Križna jama, not even in the wider Lož area [73]. The reason for this deficiency might be the same as for the absence of any Thiaridae, Neritidae and Unionidae Mollusca in the neighbouring Cerknica lake $[14,18,53,68]$.

\section{Discussion}

In one of the first reports on the Križna jama subterranean biodiversity [2] there are listed 45 troglobionts and stygobionts from Križna jama, among them 29 aquatic and 16 terrestrial species what listed this cave on the list of the world's richest caves [2,74]. In a more recent and updated list [14], the total number of troglobionts and stygobionts reached 50. Among those, 32 species are aquatic and 18 species as terrestrial. In this paper, the number of stygobionts remains the same but we omitted some doubtful taxa reported in older works and added significant new terrestrial troglobiotic taxa that were documented recently. Therefore, we present a list of 60 troglobiotic species, among them 32 aquatic and 28 terrestrial (Table 1). No new taxa have been recently described on basis of the specimens from Križna jama and thus the number of taxa with the type locality in this 
cave remains 10 species and subspecies. The fauna of Križna jama is similar to the fauna of other biodiverse caves in the Notranjska region like the Postojna-Planina cave system. In the Križna jama, there are some additional faunistic elements among the terrestrial fauna, which are related to the Dolenjska karst and are not present in Notranjska karst caves. The spider Parstalita stygia and millipede Brachydesmus inferus are such examples. Aquatic fauna is the most characteristic of the Ljubljanica river drainage system [68]. Geographically located in the temperate climatic zone and in the Dinaric mountain range, which is well known for its rich subterranean biodiversity the high number of troglobionts is not surprising. However, most hot spots of high subterranean biodiversity tend to have high primary productivity or rich organic input from the surface [2]. Contrary to some caves as the Postojna-Planina cave system, Logarček and some other caves situated in the region popularly called Notranjska triangle and well known as a prominent subterranean fauna hotspot [68], Križna jama is to be classified as oligotrophic.

There is no sinking river from the surface passing through the cave that brings significant organic material as for example Pivka River in the Postojna-Planina cave system. Waters in Križna jama are thus clean and of good quality. This is probably the main reason why there are so few non-troglobiotic elements in Križna jama waters. Fauna in Križna jama is due to lack of food, not abundant, but it is well diversified. The only exception could be attributed to Tršanov rov or the so-called Stransko jezero, where occasionally we can find a small amount of organic debris coming from the surface. The aquatic fauna is the richest there. In this part, small stonefly larvae enter the cave and are a presumably welcome food source for cave animals such as Niphargus orcinus.

The entrance to the Križna jama is situated on the foothill of Križna gora Mountain. The cave is horizontal and extends directly into the mountain. The thickness of the limestone ceiling rapidly increases and measures 50,100 and $150 \mathrm{~m}$ above the first lake close to the entrance, in the middle of the cave and in the deepest part of the cave, respectively. This immense, to some extent cracked and partly saturated habitat called epikarst, is from a biological point of view mostly unexplored and undersampled [75-77]. Epikarst tends to be a hotspot within a hotspot because the heterogeneous nature of epikarst allows for high species richness. Both the aquatic and terrestrial fauna of epikarst tends to be abundant, with epikarst copepods being the most diverse and best-studied group in some other biodiverse caves [76,77]. To further improve the knowledge of the faunal composition of Križna jama, sampling of the epikarst water seems to be the most promising, both direct sampling of dripping water as well as a detailed sampling of pools and lakes filled with percolating water. The thickness of rock deposits above the cave prevents penetration of organic particles and also incidental soil fauna elements. So food sources scarcity was noted throughout the inner parts of Križna jama too. These are the reasons that in Križna jama the terrestrial troglobiotic fauna is not abundant in numbers but it consists of numerous troglobiotic taxa without the presence of not-troglobiotic representatives. The cave is relatively well studied, however the recent finding of some, even big-sized arachnid species, so far overlooked is promising. Thus, further discoveries of specialized subterranean species in the cave are expected.

Author Contributions: Conceptualization, investigation, writing-original draft preparation, S.P.; writing-review and editing, T.P. Both authors have read and agreed to the published version of the manuscript.

Funding: This research received no external funding.

Institutional Review Board Statement: Not applicable.

Informed Consent Statement: Not applicable.

Data Availability Statement: Not applicable. 
Acknowledgments: We are deeply thankful to the local caretakers of Križna jama, namely Gašper Modic and Alojz Troha, for their help during our Križna jama visits. Tone Novak (Slovenj Gradec), Peter Kozel (Maribor) and Teo Delić (Ljubljana) accompanied us and participated in some recent cave surveys. We wish to thank Marko Lukić (Zagreb) for the preliminary determination of Collembola. Franjo Drole and Mitja Prelovšek (both IZRK ZRC SAZU Postojna) provided us with detailed speleological data and map of Križna jama.

Conflicts of Interest: The authors declare no conflict of interest.

\section{References}

1. Simić, M.; Gedei, P. Križna jama in jama Dihalnik v Grdem dolu, skrivnostni lepotici pod Križno goro v zaledju Cerkniškega polja. Natl. Geogr. Slov. Ed. 2018, 26-43.

2. Culver, D.C.; Sket, B. Hotspots of subterranean biodiversity in caves and wells. J. Cave Karst Stud. 2000, 62, 11-17.

3. Prelovšek, M. Speleogenesis and Flowstone Deposition in Križna jama. In Križna jama: Palaeontology, Zoology and Geology of Križna jama in Slovenia; Pacher, M., Pohar, V., Rabeder, G., Eds.; Verlag der Österreichischen Akademie der Wissenschaften: Wien, Austria, 2014; pp. 21-26.

4. Knez, M.; Prelovšek, M. The Geological Settings of Križna jama. In Križna jama: Palaeontology, Zoology and Geology of Križna jama in Slovenia; Verlag der Österreichischen Akademie der Wissenschaften: Wien, Austria, 2014; pp. 15-20.

5. Prelovšek, M. The Hydrogeological Setting of Križna jama. In Križna jama: Palaeontology, Zoology and Geology of Križna jama in Slovenia; Pacher, M., Pohar, V., Rabeder, G., Eds.; Verlag der Österreichischen Akademie der Wissenschaften: Wien, Austria, 2014; pp. 27-33.

6. Kogovšek, J.; Prelovšek, M.; Petrič, M. Underground water flow between Bloke plateau and Cerknica polje and hydrologic function of Križna jama, Slovenia. Acta Carsol. 2008, 37, 213-225. [CrossRef]

7. Novak, D. O barvanju potoka v Križni jami. Geogr. Vestn. 1969, 41, 75-79.

8. Müller, H. Uber Lebensswiese der Augenlosen Käfer in der Krainer Höhlen. Stettiner Entomol. Zeitung 1857, 18, 65-74.

9. Hauffen, H. Beiträge zur Grottenkunde Krain's. Jahresh. des Vereines des Krainischen Landes-Mus. 1858, 2, 40-53.

10. Joseph, G. Erfahrungen im wissenschaftlichen Sammeln und Beobachten der den Krainer Tropfsteigrotten eigenen Arthropoden. Separat-Abdruck aus der Berliner Entomol. Zeitschrift 1882, 26, 1-100.

11. Jeannel, R. Revision des Bathysciinae. Biospeol. XIX-Arch. Zool. Expérimentale Générale 1911, 5, 1-641.

12. Jeannel, R. Monographie des Bathysciinae. Arch. Zool. Expérimentale Générale 1924, 64, 1-436.

13. Wolf, B. Animalium Cavernarum Catalogus; Dr. W. Junk's Gravenhage: Berlin, Germany, 1937.

14. Sket, B.; Stoch, F. Recent Fauna of the Cave Križna jama in Slovenia. In Križna jama: Palaeontology, Zoology and Geology of Križna jama in Slovenia; Pacher, M., Pohar, V., Rabeder, G., Eds.; Verlag der Österreichischen Akademie der Wissenschaften: Wien, Austria, 2014; pp. 45-55.

15. Stammer, H.J. Zwei neue troglobionte Protozoen: Speleophrya troglocaridis n. g., n. sp. von den Antennen der Hohlengarnele Troglocaris schmidti Dorm. und Lagenophrys monolistrae n. sp. vod den Kiemen (Pleopoden) der Hohlenasselgattung Monolistra. Arch. Für Protistenkd. 1935, 84, 518-527.

16. Matjašič, J. Verlaufige mitteilungen uber Europaische Temnocephalen. Biološki Vestn. 1958, 6, 60-65.

17. Kuščer, L. Drei neue Höhlenschnecken. Glas. Muzejskega Društva Slov. 1928, 7-8, 50-51.

18. Bole, J. Mehkužci Cerkniškega jezera in okolice. Acta Carsol. 1979, 8, 204-236.

19. Kuščer, L. Höhlen- und Quellenschnecken aus dem Flussgebiet Ljubljanica. Arch. Für Molluskenkd. 1932, 64, 48-62.

20. Bole, J. Rod Zospeum Bourguignat 1856 (Gastropoda, Ellobiidae) v Jugoslaviji. Razpr. SAZU 1974, 17, $249-291$.

21. Stoch, F. A new genus and two new species of Canthocamptidae (Copepoda, Harpactioida) from caves in northern Italy. Hydrobiologia 1997, 350, 49-61. [CrossRef]

22. Joseph, G. Über die Grotten in der Krainer Gebirge und deren Tierwelt. Jahresbericht der Schlesischen Gesellschaft für Vaterländische Kult. Breslau 1869, 46, 48-52.

23. Strouhal, H. Landasseln aus Balkanhöhlen, gesammelt von Prof. Dr. Karl Absolon. 10. Mitteilung. In Studien aus dem Gebiete der allgemeinen Karstforschung, der wissenschaftlichen Höhlenkunde, der Eiszeitforschung und den Nachbargebieten; Barvič \& Novotný: Brno, Czech Republic, 1939; pp. 1-37.

24. Strouhal, H. Eine neue Höhlen-Sphaeromatide (Isop.). Zool. Anz. 1928, 77, 84-92.

25. Hamman, O. Europäische Höhlenfauna. Eine Darstellung der in den Höhlen Europas lebenden Tierwelt mit besonderer Berücksichtigung der Höhlenfauna Krains; Hermann Costenoble: Jena, Germany, 1896.

26. Kratochvil, J. Cavernicole Dysderae. Prirodoved. Pr. Ust. Češkoslovenske Akad. ved v Brne 1934, 2, 165-226.

27. Kratochvil, J. Liste générale des araignées cavernicoles en Yougoslavie. Prirodosl. Razpr. 1934, 2, 165-226.

28. Deeleman-Reinhold, C.L. Beitrag zur Kenntnis höhlenbewohnender Dysderidae (Araneida) aus Jugoslawien. RazpraveDissertationes SAZU, Ljubljana 1971, 14, 93-120.

29. Deeleman-Reinhold, C.L. Revision of the cave-dwelling and related spiders of the genus Troglohyphantes Joseph (Linyphiidae), with special reference to the Yugoslav species. Razprave-Dissertationes SAZU, Ljubljana 1978, 23, 1-221.

30. Fage, L. Etudes sur les araignées cavernicoles. III. Sur le genre Troglohyphantes Biospelogica XL. Arch. Zool. Expérimentale Générale 1919, 55, 55-148. 
31. Beier, M. Die Höhlenpseudoscorpione der Balkanhalbinsel. Biospeol. Balc. 1939, 4, 1-83.

32. Gardini, G. Gli Chthonius (Globochthonius) D'Italia e di Slovenia (Pseudoscoripines Chthonidae). Gortania, Bot. Zoolgia 2009, $31,53-64$.

33. Kozel, P.; Delić, T.; Novak, T. Nemaspela borkoae sp. nov. (Opiliones: Nemastomatidae), the second species of the genus from the Dinaric Karst. Eur. J. Taxon. 2020, 717, 90-107. [CrossRef]

34. Mršić, N. Attemsiidae (Diplopoda) of Yugoslavia. Razpr. SAZU 1987, 27, 101-168.

35. Strasser, K. Diplopoden des jugoslavischen Draubanats. Prirodosl. Razpr. 1940, 4, 13-85.

36. Mršić, N. Polydesmida (Diplopoda) of Yugoslavia. Razpr. SAZU 1988, 29, 69-112.

37. Jeannel, R. Monographie des Trechinae (3); Les Trechini Cavernicoles; L'Abeille: Paris, France, 1928.

38. Drovenik, B.; Peks, H. Catalogus faunae Carbidae del Balkanländer, Coleoptera, Carabidae. Shwanfelder Colopterologische Mitteilungen 1994, 1, 1-103.

39. Daffner, H. Revision der Anophthalmus-Arten und -Rassen mit lang und dicht behaarter Körperoberseite. Mitteilungen der Münchner Entomol. Gesellschaft 1996, 86, 33-78.

40. Müller, J.G. Über einige Krainer Anophthalmen. Wiener Entomol. Zeitung 1921, 38, 91-99.

41. Nonveiller, G.; Pavićević, D. Description d'une sous-espèce nouvelle et de six espèces nouvelles du genre Machaerites Miller, 1855 de Slovénie et de Croatie (Coleoptera, Pselaphinae, Bythinini). Nouv. Rev. Entomol. 2001, 18, 317-333.

42. Jeannel, R. Les Psélaphides troglobies de la Slovénie. Notes Biospéologiques 1954, 9, 7-15.

43. Poggi, R. Forme nuove o poco note di Pselaphidae cavernicoli del Friuli-Venezia Giulia e della Jugoslavia. Mem. della Soc. Entomol. Ital. 1991, 70, 201-224.

44. Müller, G. I Pselafidi cavernicoli del Carso Adriatico settentrionale (Venezia Giulia e Carniola). Boll. della Soc. Adriat. di Sci. Nat. Trieste 1947, 43, 133-146.

45. Pretner, E. Coleoptera, Catopidae, Bathysciinae. Cat. Faunae Jugoslaviae, SAZU, Ljubljana 1968, 3, 1-60.

46. Bognolo, M. Il Genere Bathyscimorphus (Coleoptera: Cholevidae). Coleoptera 2002, 6, 1-33.

47. Bognolo, M.; Vailati, D. Revision of the genus Aphaobius Abeille de Perrin, 1878 (Coleoptera, Cholevidae, Leptodirinae). Scopolia 2010, 68, 1-75.

48. Zörrer, J. Beschreibung einer Berghöhle bei Heiligen Kreuz unweit Laas. Beiträge zur Naturgeschichte, Landwirtschaft und Topogr. Herz. Krain 1838, 1, 76-88.

49. Shaw, T. Foreign Travellers in the Slovene Karst 1486-1900; ZRC Publishing: Ljubljana, Slovenia, 2008.

50. Hohstetter, F. Die Kreuzberghöhle bei Laas in Krain. Denkschriften der Kais. Akad. der Wissenschaften, Math. Cl. 1881, 43, 1-18.

51. Pohar, V. Križna jama: Description and History of Research. In Križna jama: Palaeontology, Zoology and Geology of Križna jama in Slovenia; Pachner, M., Pohar, V., Rabeder, G., Eds.; Verlag der Österreichischen Akademie der Wissenschaften: Wien, Austria, 2014; pp. 1-6.

52. Müller, J.G. Vier neue Anophthalmen aus Krain (Col. Carab.). Wiener Entomol. Zeitung 1923, 40, 101-106. [CrossRef]

53. Bole, J. Taksonomska, ekološka in zoogeografska problematika družine Hydrobiidae (Gastropoda) iz porečja Ljubljanice. Razpr. (Dissetationes), Cl. IV; SAZU 1967, 10, 57-108.

54. Martinez-Ansemil, E.; Sambugar, B.; Giani, N. Groundwater Oligochaetes from southern-Europe. I. A new genus and three new species of Rhyacodrilinae (Tubificidae) with a redescription of Tubifex pescei (Dumnicka) comb. n. Ann. Limnol. 1997, 33, 33-44. [CrossRef]

55. Karaman, S. Taksonomska, Zoogeografska i Ekološka Studija Oligochaeta u Području Planine, Cerknice i Postojne; Univerza v Ljubljani: Ljubljana, Slovenija, 1978.

56. Sket, B. O favni v Križni jami. In Notranjski List III; Kulturna skupnost Cerknica: Cerknica, Slovenia, 1986; pp. $25-28$.

57. Presetnik, P.; Koselj, K.; Zagmajster, M. Atlas netopirjev (Chiroptera) Slovenije. Atlas of the bats of Slovenia; Presetnik, P., Koselj, K., Zagmajster, M., Eds.; Center za kartografijo favne in flore: Miklavž na Dravskem polju, Slovenia, 2009.

58. Presetnik, P.; Troha, A. Prezimujoči netopirji. In Križna Jama; Kržič, M., Ed.; Društvo ljubiteljev Križne jame: Grahovo, Slovenia, 2010; pp. 24-32.

59. Pipan, T.; López, H.; Oromí, P.; Polak, S.; Culver, D.C. Temperature variation and the presence of troglobionts in terrestrial shallow subterranean habitats. J. Nat. Hist. 2010, 45, 253-273. [CrossRef]

60. Pavlek, M.; Mammola, S. Niche-based processes explaining the distributions of closely related subterranean spiders. J. Biogeogr. 2021, 48, 118-133. [CrossRef]

61. Novak, T.; Kozel, P. Hadzinia ferrani, sp. n. (Opiliones: Nemastomatidae), a highly specialized troglobiotic harvestman from Slovenia. Zootaxa 2014, 3841, 135-145. [CrossRef] [PubMed]

62. Kos, A. Genetska Raznolikost Strig Kompleksa vrsta Lithobius Stygius v Severnih Dinaridih, Magistrasko Delo; Univerza v Ljubljani: Ljubljana, Slovenia, 2021.

63. Strasser, K. Die Diplopoden Sloweniens. Acta Carsol. 1966, 4, 159-220.

64. Strasser, K. Neue Acherosomen (Diplopoda Ascospermophora). Prirodosl. Razpr. 1935, 2, 231-244.

65. Strasser, K. Uber Diplopoden Jugoslawiens. Senckkenbergiana Biol. 1971, 52, 313-345.

66. Chappius, P.A. Copépodes (première serie) avec l'énumeration de tous les Copépodes cavernicoles connus en 1931, Biospeologica 59. Arch. Zool. Expérimentale Générale 1933, 76, 1-57. 
67. Petkovski, T.K. Neue höhlenbewonende Harpacticoida (Crustacea, Copepoda) aus Slovenien. Acta Musei Maced. Sci. Nat. 1983, 16, 177-205.

68. Sket, B. The cave Fauna in the triangle Cerknica-Postojna-Planina (Slovenia, Yugoslavia), its conservation importance. Varst. Narave 1979, 13, 45-59.

69. Kralj, P. Sedimentary Deposits in Kittl's Bear Gallery in Križna Jama Cave (Slovenija). In Križna jama: Palaeontology, Zoology and Geology of Križna jama in Slovenia; Pacher, M., Pohar, V., Rabeder, G., Eds.; Verlag der Österreichischen Akademie der Wissenschaften: Wien, Austria, 2014; pp. 35-43.

70. Gospodarič, R. Fluvialni sedimenti v Križni jami (Fluvial sediments in Križna jama). Acta Carsol. 1974, 6, 327-366.

71. Jeršek, M.; Žorž, M. Kremen iz okolice Cerknice. In Mineralna bogastva Slovenije. Scopolia 2006, 3, 410-417.

72. Sket, B. Distribution of Proteus (Amphibia: Urodela: Proteidae) and its possible explanation. J. Biogeogr. 1997, 24, 263-280. [CrossRef]

73. Sket, B.; Zakšek, V. European cave shrimp species (Decapoda: Caridea: Atyidae), redefined after a phylogenetic study; redefinition of some taxa, a new genus and four new Troglocaris species. Zool. J. Linn. Soc. 2009, 155, 786-818. [CrossRef]

74. Culver, D.C.; Pipan, T. Subterranean Ecosystems. In Encyclopedia of Biodiversity; Levin, A.S., Ed.; Academic Press: Wlatham, MA, USA, 2013; pp. 49-62.

75. Pipan, T.; Brancelj, A. Ratio of copepods (Crustacea: Copepoda) in fauna of percolation water in six karst caves in Slovenia $=$ Delež ceponožcev (Crustacea: Copepoda) v favni preniklih voda v šestih kraških jamah v Sloveniji. Acta Carsol. 2001, 30, 257-265.

76. Culver, D.; Pipan, T. Shallow Subterranean Habitats. Ecology, Evolution, and Conservation; Oxford University Press: Oxford, UK, 2014.

77. Pipan, T. Epikarst-A Promising Habitat: Copepod fauna, Its Diversity and Ecology: A Case Study from Slovenia (Europe); ZRC SAZU Publishing: Ljubljana, Slovenia, 2005. 